\title{
Application of Mobile Phone as a Motivational Tool in the ESP Classrooms of Dhofar University
}

\author{
K. Thomas Baby \\ Assistant Professor, Dhofar University, Salalah, Oman \\ kthomasbaby@hotmail.com
}

DOI: https://doi.org/10.36892/ijlls.v2i1.116

$\begin{array}{ll}\text { Received: } & \text { Abstract } \\ \text { 12/01/2020 } & \text { The present paper investigated the factors of motivation and the role of } \\ & \text { teachers in motivating English language learners in the ESP classes of Dhofar } \\ \text { Accepted: } & \text { University as well as the significance of motivation in teaching and learning } \\ \text { 16/03/2020 } & \text { through mobile application technology. Mobile phones are handy devices that } \\ & \text { are readily available with all the students in universities and colleges } \\ & \text { nowadays. Furthermore, the innovative use of mobile applications and } \\ \text { Keywords: } & \text { internet technology is very common among the undergraduate students. This } \\ \text { Mobile Phones; } & \text { paper is a detailed description of some of the teaching strategies employed } \\ \text { Learners; Technology; } ; & \text { through mobile phones to motivate the students who have very low level of } \\ \text { Application } & \text { motivation. Since lack of motivation among students is a common challenge } \\ & \text { faced by most of the ELT teachers in their classrooms, practical solutions } \\ & \text { centred on mobile applications is the focus of this study. Furthermore, } \\ & \text { supplementing classroom practices with mobile application technology can } \\ \text { promote learner autonomy and peer learning opportunities within the } \\ \text { classroom resulting in a visible rise in the motivational graph of the whole } \\ \text { class. This paper is also a practical account of how mobile applications can } \\ \text { be integrated into classroom teaching without affecting the traditional } \\ \text { syllabus of a conventional university curriculum. }\end{array}$

INTRODUCTION

The digitalization of education and educational resources is a direct outcome of the rapid technological development of our times. Therefore, mobile devices can be used effectively in the classroom not only to promote and develop students' electronic skills but also to enhance their involvement and motivation in various learning activities. Above all, it will prepare them adequately for the practical world outside the school. Furthermore, supplementing classroom practices with mobile application technology can promote learner autonomy and peer learning opportunities within the classroom. This experiment of using mobile application technology in the classroom eventually resulted in a visible rise in the motivational graph of the whole class as testified by students' performance in their tests.

Motivation is one of the chief elements in any successful learning activity. Undoubtedly, motivation is the primary factor in the acquisition of a second language as it requires on-going practice and conscious effort to focus on all the four skills such as reading, writing, listening and speaking. The more motivated people are, the more successful they can be in mastering English language or another foreign language. "Motivation is one of a number of what researchers call individual differences (traits that vary across individual). Motivation to learn another language is conceived as the degree and type of "wanting to learn" and has been shown to correlate significantly with how far learners get" (Vanpatten \& Benati, 2015, p. 144).

Motivation has been regarded as one of the most important reasons that make someone do something to move forward. Motivation may be the reason of someone's success or a 
person can achieve his goal just because he got motivated by someone or something. Motivation is an effective element and a powerful factor which make someone learn English language or any other language. Students who have the desire to learn English are close to own the language and to continue moving forward. Motivation is highly expected and encouraged in all areas and walks of life. The role of teachers in motivating students is vital. If there is no encouragement from the teachers, when students perform well or when they are below average level, all the efforts of the teachers will be futile. Hence, teachers need to pay attention to motivate their students in moulding and guiding them possibly in every skill. "Attribution Theory views motivation as deriving from the explanations that learners give for their progress in learning a second language" (Ellis, 2015, p. 50)

Ellis (2015) described the two main types of motivation which can be classified as internal and external motivation. This Theory was built around the common-sense notion that people are motivated by both external factors such as rewards, grades, or the opinions of others and by internal ones such as personal interests, curiosity, or experiencing an activity as fun. The theory was later developed as a model based on the distinction between intrinsic motivation and extrinsic motivation. They defined extrinsically motivated behaviours as 'those actions carried out to achieve some instrumental end' and intrinsic motivation as 'motivation to engage in an activity because it is enjoyable and satisfying in itself for the participant.

\section{The Purpose and Objectives of the Study}

The purpose of this study is to find out how the application of mobile phones, for academic activity within the classrooms, can affect the motivation level and academic performance of the undergraduate students at Dhofar University. One of the problems the researcher faced in the undergraduate ESP classes is the attention deficiency of students due to their excessive pre-occupation with their mobile devices during the class hours. In order to overcome this challenge, the author wanted to transfer some of the language learning activities to mobile aided learning. Therefore, this study is the result of an experiment in ESP classes for the undergraduate students of business and management studies at Dhofar University.

Through this experimental research, the objective was to find out the effectiveness of mobile supported learning in enhancing the motivation level of students. Teachers must understand their students' behaviour patterns for developing meaningful relationship with learners because they come from different backgrounds, interests and goals. Moreover, they possess different types of personality traits. If the teachers understand their students better, they can create some suitable teaching ways of instruction for each student. Therefore, creating a good relationship between a teacher and his student and developing this relationship will lead to a comfortable and enjoyable teaching strategy for the students to learn easily through the teacher. A learner's motivation is influenced by other learners as well. Therefore, the dynamics of a classroom or of a "learning group affect the extent to which an individual learner is motivated, both overall and when performing specific tasks" (Ellis, 2015, p. 55). This refers to the executive motives related to the immediate learning environment and experience. Important factors here are the impact of the teacher, the curriculum, the peer group, and the experience of success.

\section{Questions of the Study}

The two basic questions this study proposes to answer are the following:

1. Can mobile-aided learning within the classroom enhance the motivation level of the participants? 
2. Can mobile-supported learning improve the scores of participants in their tests and examinations?

\section{Intrinsic Motivation}

Intrinsic motivation is the behaviour that is related to an internal reward. It is the type of motivation which appears inside the individual because it is naturally satisfied with what he is doing, as opposed to extrinsic motivation, which arises outside the person. It happens when someone or some people do something not to get an external reward, but because they are simply enjoying what they do. Think about your motivation for reading this research paper or any other particular study just because you find it interesting and want to know more about the topic and not to earn a reward. Intrinsic motivation is one of the kinds of motivation that refers to behaviour which leads you to a personal goal, for example, participating in an activity for having fun rather than the desire for earning some reward such as money or a prize. Participating in some competition just to enjoy and have fun, cleaning your bedroom because you like seeing it clean and beautiful every day and studying some course because you find it interesting and enjoyable, are examples of intrinsic motivation.

\section{Extrinsic Motivation}

Extrinsic motivation is basic behaviour which drives someone to a particular reward. This reward can be money, grades, or prizes. Extrinsic motivation appears from outside people, whereas intrinsic motivation arises from the mind of the people. For example, if you are reading this paper in order to gain new information only to be used in your examination to get high marks, your motivation is external. In short, extrinsic motivation appears when we want to avoid a punishment or when we want to get some reward through some activity. Therefore, you are externally motivated in order to get something that would be useful for you in return or avoid something uncomfortable for you. There are many examples of extrinsic motivation, participating in some competition to win a particular prize, cleaning your bedroom to avoid the displeasure of your parents or trying to get good grades to get a scholarship for your higher studies are some of the examples of extrinsic motivation.

\section{Instrumental and Integrative Motivation}

Students who have an instrumental motivation want to study and learn English for a practical reason. For example, they may learn a language for getting into a college or a university, or perhaps for having a good career or high salary. Students with integrative motivation plan on learning English language in order to understand and know better about English language and its correct usage.

\section{Mobile Application Technology in Omani Classrooms}

Many higher educational institutions in Oman make effective use of technology in their teaching and learning activities. Most of the higher educational institutions in Oman have equipped their classrooms with computers and LCD projectors. These electronic devices are used effectively by many teachers in the classrooms. In the Omani context, the application and use of technology rarely go beyond the confines of classrooms. Teachers mainly exploit the possibilities of technology only in their instructional activities. This is due to the fact that all the assessments, evaluations and grading are still on paper-based mode. Students rarely take online examinations for the purpose of assessment except in IT courses. All the important examinations are paper-based and students do not use laptops or iPads in the classrooms except for project work. Therefore, instructional uses of mobile phones or digital 
devices in the classrooms by students are not a familiar concept for learners in the higher education institutions of Oman.

In digital or paperless classrooms, all academic activities are essentially digitalized because textbooks and note books are not allowed in the classroom. All examinations, quizzes and assessments and grading are implemented in the in paperless mode. Although, paperless classroom has not become a reality in Oman, students often exhibit some of the essential characteristic of digital classrooms. An observational analysis of students' behaviour patterns revealed that many undergraduate students of Dhofar University unconsciously practice some of the basic concepts paperless classroom.

\section{Mobile Application Technology and Motivation}

The idea of establishing digital classrooms was originally intended to promote and develop the electronic skills of the students and to prepare them for the practical world outside school (De Bonis \& De Bonis, 2011). However, it served the higher purpose of generating motivation in new generation learners because of their attraction for digital devices. According to Ferguson (2017) digital devices are instrumental in improving students' engagement and motivation in their learning activities. Watfa \& Audi (2017) believes that digital devices will be an added impetus for active participation from all students during class hours. Consequently, it will maximize the learning outcome by the immediate real-time feedback offered for improving the performance of students.

Digital classrooms are basically learner-centered because students can explore and structure their knowledge through interaction with other learners and through internet. Therefore Grigoryan \& Babayan (2015) believe that the teacher's epistemology of knowledge is conditioned by his/her competence to provide appropriate technological instruction to the students. As a result, Mobile Application Technology in classroom offers a new paradigm of learning and not just a new tool or a method of teaching and learning (Yuniarti, 2014). An observational analysis of students' behaviour patterns revealed that many undergraduate students enjoy using their smart phones most of the time. They are seen engaged with these devices secretly even during the lecture time.

\section{LITERATURE REVIEW}

Numerous studies have been conducted on the effectiveness of mobile learning. Evidence on academic achievement is provided by researches from different parts of the world. For example, some researchers like ( Froese et al., 2012; Huang et al., 2010; Lu, 2008; Sung \& Mayer, 2013; Thomas \& Orthober, 2011) focused their attention on the improvement in learning outcome. On the other hand, many others such as (Huang et al., 2010; Burkhardt \& Cohen, 2013; Brett, 2011; Gedik et al., 2012; Navaridas et al., 2013) provided differing information on the impact of mobile learning and its role in enhancing the motivation of students in their learning activities. However, many teachers and students agree that mobile devices can be considered to be a motivating factor for teaching and learning.

Most of the studies testify that mobile learning has a positive impact on student motivation. Specifically Huang et.al (2010) found potential correlation between mobile devices and student motivation. According to them, traditional mode of textbook learning is widely substituted by mobile learning nowadays because of its role in generating motivation in students. Furthermore, they observed higher engagement, enthusiasm and motivation among mobile users than students who depended on textbook learning. In addition, these researchers verified that electronic learning with competitive elements led to an increase of motivation to outperform peers.

The findings of another case study by Ciampa (2014) based on Malone and Leppers taxonomy of intrinsic motivation also corroborate the fact that learner motivation can be enhanced considerably through the application of mobile learning technology in classrooms. 
In addition to its theoretical foundations, the study also explored the important practical aspects of motivation in technology supported learning environments. This case study also positively affirmed the role of mobile application technology in enhancing learner motivation.

\section{METHODOLOGY}

The methodology adopted for this study is basically an experimental analysis of using mobile application technology for teaching learning activity in various ESL classes of Dhofar University . In order to corroborate the finding of the personal experiences of the researcher, a class of 28 students is used for a pilot study to ascertain the effectiveness of using mobile phones for learning activity within the classrooms.

\section{Participants}

The participants of this study are specifically 18 female students and 10 male students from an ESL class of undergraduate students doing business studies at Dhofar University. It also includes ESL undergraduate students of other classes in general for the purpose of observational analysis. The pilot study group is demarcated for specific grammar lessons through mobile application technology in order to corroborate the observational findings and analysis of the author from other ESL classes.

A specific case in context that led to this study is the unexpected use of a digital text book of English Language in an engineering class. When many male students of the class said they do not have the text book, they were asked to get a photocopy of the particular unit. One of them immediately asked the teacher why don't you use LCD projector and display the lesson for the whole class. He knew that a soft copy of the book was stored in the computer for the class listening activity. This was an eye-opener to the EFL/ESL teacher. On that day, the reading activity class was taken using the digital version of English for engineering textbook. The whole class enjoyed the fresh experience of looking on the screen in an English reading activity class instead of using their textbooks.

Gradually the comprehension level of many of these students improved significantly as reflected in their periodic vocabulary quizzes and reading comprehension tests. Therefore, it was extended to the whole class for completing grammar and writing tasks. This innovative practice of supplementing mobile application technology in task based learning activities produced perceptible changes in the internal motivation level of many students. The positive results from the free use of mobile devices for learning activities within the classroom have encouraged the researcher to undertake an experimental study in one of the undergraduate at Dhofar University.

\section{Instruments and Procedures of the Study}

This paper is a detailed description of the some of the teaching strategies employed through mobile phones to motivate the students who have very low level of motivation. Since lack of motivation among students is a common challenge faced by most of the ELT teachers in their classrooms, practical solutions centred on mobile applications is the focus of this study as it is the favourite device of most of the students. Moreover, this is a specific case study of a group of students in Dhofar University who were habitual late comers in an ESP undergraduate class. A group of six male students were asked to take the photograph of the current page of the textbook being taught in the class. These students were made to sit in a separate group and use the copy of the photograph they have taken with their mobile phones. 
Occasionally they were asked to find the meaning of certain vocabulary in the reading text to make sure of their participation in the class.

The partial use of mobile application technology in the ESP classrooms of Dhofar University was necessitated by the lack of student motivation noticed in an undergraduate class by this author. The choice of mobile/smart phones for enhancing motivation in the ESP undergraduate class is based on a very personal experience of this author. In the grammar classes, the usual practice was to explain initially, the rules of the grammatical concept. Consequently, it would be followed by the supply of worksheets to test the students' understanding of the concept. The explanation of concepts lasting up to maximum 15 minutes is usually done at the beginning of the class. During this time, it was noticed that many students were secretly engaged with their mobile phones under the pretext of listening to the teacher.

The above mentioned episode is a clear instance of lack of motivation on the part of the students. On deep reflection, the author realized that it was the mobile phone and its different applications that attracted and engaged students more than the verbal explanations from the teacher. Therefore, it was decided that the initial part of teaching the grammatical concept would be substituted with learner autonomy. The students were allowed 10 minutes to learn the grammar topic independently through the free use of their mobile phones. The teacher would act only as a facilitator in this task by moving around the groups to make sure that students are using their mobiles phones only for the task of learning the concept. If they fail to find out all aspects of the concept, it would be supplemented by the teacher during the last 5 minutes of the session.

Another instance was from the English writing activity class for the undergraduate students of the business stream. The teacher was using the white board in a summary writing activity in this business English (ESP) class. After explaining how to write the summary of a passage, the summary of the paragraph was written on the whiteboard as an example for the students. The teacher then asked the students to copy it in their notebook as a model answer for them. When the teacher went around the class to see how they are doing the writing task, he found a group of boys talking to each other without doing their writing task on the paper. On being asked why they are talking to each other instead of writing the summary, one of the boys showed the photo of the summary that the teacher had written on the white board and said he would copy it on paper at home. Even though it annoyed the teacher and certainly not an emulating example to be followed by other students, it turned out to be an enlightening experience for the teacher.

\section{An Observational Analysis}

A reflection on the episode of the writing activity class made the teacher to adopt a better strategy in his classroom. On reflection, the teacher realized that performing a multitask like speaking and writing simultaneously in the class impromptu can cause certain problems. For example, while writing the summary on the board, the teacher had missed out a word inadvertently but it was added later on his re-reading of what was written on the whiteboard. Of course, it was added after the boy had photographed the summary in his smart phone. So the teacher decided that he would prepare even the simplest writing task in advance and always use the digital media to display it for the students instead of doing the task impromptu in the class.

The above episodes from the undergraduate EFL/ESL classes are recounted here only to show that students are naturally inclined towards the idea of digital or paperless classrooms. Although they are ignorant of the theoretical implications of paperless classrooms, unconsciously they practice the basic tenets of this concept through the innovative use of the digital devices at their disposal. It is an indication that gradually the 
student community in Oman will move towards the goal of paperless classrooms. As the above episodes illustrate, even the teachers are moving slowly and decidedly towards the same direction. This is evident from the increased use and application of computer and LCD projector for the teaching learning activity in the classrooms.

Teachers in Dhofar University used to provide photocopies of the syllabus, assessment schedules and homework tasks in the classroom. Nowadays, most of the teachers post them on Moodle, the learning management system (LMS) of Dhofar University. Moodle can be customized by individual teachers and accessed by all his/her students for all their class activity needs. Most of the teachers use this LMS for posting their homework tasks, assignments and even hand-outs which can be printed out. Students can easily log into the system and get information about all the activities that happen in the class. Sometimes teachers post final grades of the continuous assessments just before the final examinations. This is done without the name of the student but only with their ID numbers to conceal the identity of individual students. All these digital applications practiced currently in Dhofar University is an indicator that it can gradually move into paperless classrooms in the near future at least in certain disciplines after further studies and research.

\section{RESULTS AND DISCUSSION}

The pilot study of the experimental group consisted of 18 female students and 10 male students of the undergraduate class of the business stream had 2 weeks of blended grammar lessons using mobile application technology. After introducing mobile application technology for learning grammar, the overall attendance of male students in the class increased substantially from $55 \%$ to $85 \%$. However, the attendance of female students did not show any significant change. It was $95 \%$ before introducing mobile learning activity in the class but increased only slightly to $96 \%$ after the introduction of mobile learning. However, the class average of the test score for male students improved significantly by $15 \%$ after introducing mobile learning in the class but the class average for female students increased only by $3 \%$ in the grammar tests administered after introducing mobile learning applications in the class.

The specific task given in the class was about present perfect tense. 15 minutes each from two sessions were utilized for this experiment. Instead of explanations from the teacher, the rules for constructing present perfect sentences were elicited from the students who utilized their mobile phones for this learning activity. This simple but innovative learning activity supported by technology enhanced the motivation level of the students as reflected in their attendance and the score of the subsequent grammar tests. During this independent learning session, the engagement and participation of the students also testified to their enhanced motivation. In terms of learning outcome, this experiment can be recommended because students scored higher mark in this test than their previous test taught in the traditional method.

The above episode is mentioned elaborately to vindicate that mobile application technology can enhance students' motivation as they are naturally inclined towards the idea of using mobile/smart phone whenever possible. The higher score obtained in a rather difficult topic (present perfect tense) learned through the digital mode is a further indication that learners prefer mobile application technology rather than traditional mode of classroom lectures. Although many learners are ignorant of the theoretical implications of digital classrooms, most of them endorse the innovative use of the digital devices in classrooms. In short, the effective use of mobile technology within the classrooms for teaching and learning activity will not only enhance the motivational level of students but also help to improve test performance of students as shown in this experimental pilot study. 


\section{CONCLUSION}

Motivation is found to be the factor that oils the success of individuals in various fields and activities. In education, motivation plays a significant role in helping learners develop and grow in knowledge and skills. For instance, motivated students are likely to be better learners than those who don't receive encouragement and support. Thus, motivation is a key factor for children's learning, and growth. Motivation can come from various sources. For instance, an individual's family is an important source of motivation and encouragement. Family members need to encourage each other to embrace civic behaviours and act as good citizens. Moreover, schools, and other learning institutes can also be useful sources of motivation for students to learn good behaviours and achieve excellent results. Our friends also can motivate us by giving us support and encouragement whenever we need. All in all, the society at large can play positive roles in raising its members' spirits for great achievements.

This study sheds light on the importance of mobile devices in the classroom. While the study did not reveal a statistically significant effect from mobile learning on academic achievement, it did offer valuable insight on students' motivation to learn by mobile devices. There was a statistically significant change in students' motivation for learning due to their use of mobile devices. Students showed a greater change in their perception of learning when using mobile devices. Students believed they had a greater change in their learning using mobile devices as compared to paper-learners. Those students were more confident in their learning. In addition, students using mobile devices showed a greater change in their interest and motivation to learn as compared to paper learners. Overall, the students felt more excited and driven to learn when using mobile devices.

Although a number of studies offered no significant improvement in academic grades among students who employed mobile phones for their learning activities, almost all the studies have recommended the use of mobile devices in the classroom for the purpose of enhancing motivation and engagement in their learning activities. Therefore, innovative use of mobile devices should be encouraged in the classroom for empowering students through regulated task basked instruction for optimum output. This finding is significant in many ways because it is an effective method for teachers to refresh and renew their classroom instruction in order to motivate and engage even disinterested students in their class and to enhance their academic performance.

\section{REFERENCES}

Brett, P. (2011). Students' experiences and engagement with SMS for learning in higher education. Innovations in Education \& Teaching International, 48(2), 137-147. http://dx.doi.org/10.1080/14703297.2011.564008

Burkhardt, A., \& Cohen, S. F. (2012). "Turn your cell phones on": Mobile phone polling as a tool for teaching information literacy. Communications in Information Literacy, 6(2), 191-201. http://dx.doi.org/10.7548/cil.v6i2.185

Ciampa, K. K. (2014). Learning in a mobile age: An investigation of student motivation. Journal of Computer Assisted Learning, 30(1), 82-96. doi:10.1111/jcal.12036

De Bonis, S., \& De Bonis, N. (2011). Going green: Managing a paperless classroom. US-China Education Review, A(1), 83-87.

Ellis, R. (2015). Understanding Second language Acquisitions. (2nd ed.). OXFORD : Oxford University Press.

Eills, R., \& Shintani, N. (2014). Exploring language pedagogy through Second language Acquisition Research. London : Routledge Taylor And Francis Group. 
Ferguson, J. M. (2017). Middle school students' reactions to a 1: 1 iPad initiative and a paperless curriculum. Education and Information Technologies, 22(3), 1149-1162. https://doi.org/10.1007/s10639-016-9480-2

Froese, A.D., Carpenter, C.N., Inman, D. A., Schooley, J. R., Barnes, R. B., Brecht, P. W., \& Chacon, J.D. (2012). Effects of classroom cell phone use on expected and actual learning. College Student Journal, 46(2), 323-332.

Gedik, N., Hanci-Karademirci, A., Kursun, E., \& Cagiltay, K. (2012). Key instructional design issues in a cellular phone-based mobile learning project. Computers \& Education, 58(4), 1149- 1159. http://dx.doi.org/10.1016/j.compedu.2011.12.002

Grigoryan, T., \& Babayan, N. (2015). Digital natives and digital immigrants in a paperless classroom. International Journal of Arts \& Sciences, 8(1), 289-296.

Huang, Y. M., Lin, Y. T., \& Cheng, S. C. (2010). Effectiveness of a mobile plant learning system in a science curriculum in Taiwanese elementary education. Computers \& Education, 54(1), 47-58. http://dx.doi.org/10.1016/j.compedu.2009.07.006

Lu, M. M. (2008). Effectiveness of vocabulary learning via mobile phone. Journal of Computer Assisted Learning, 24(6), 515-525. http://dx.doi.org/10.1111/j.1365-2729.2008.00289.x

Navaridas, F., Santiago, R., \& Tourón, J. (2013). Opinions from teachers in the Fresno area of Central California regarding the influence of mobile technology on their students' learning. RELIEVE - e-Journal of Educational Research, Assessment and Evaluation, 19 (2), 1-18. http://dx.doi.org/10.7203/relieve.19.2.3047

Sung, E. \& Mayer, R.E. (2013). Online multimedia learning with mobile devices and desktop computers: An experimental test of Clark's methods-not-media hypothesis. Computers in Human Behavior, 29(3), 639-647. https://doi.org/10.1016/j.chb.2012.10.022

Vanpatten, B., \& Benati, A. G. (2015). Key Terms In Second Language Acquisitions. (2nd ed.). London : Bloomsbury Academic An Imprint Of Bloomsbury Publishing Plc.

Watfa, M. K., \& Audi, D. (2017). Innovative virtual and collaborative teaching methodologies. Behaviour \& Information Technology, 1-11. https://doi.org/10.1080/0144929X.2016.127580

Thomas, K., \& Orthober, C. (2011). Using text-messaging in the secondary classroom. American Secondary Education, 39(2), 55-76.

Yuniarti, W. D. (2014).Utilizing learning platform for paperless classroom. Vision: Journal for Language and Foreign Language Learning, 3(2), 105. https://doi.org/10.21580/vjv3i2295

\section{AUTHOR'S BIO:}

Dr. Thomas Baby is currently Assistant Professor of English at DHOFAR UNIVERSITY, SALALAH, OMAN. He has Published books and research articles extensively in ELT area and presented papers at various international conferences such as TESOL FRANCE, TESOL ARABIA and EURASIA conferences. 